\title{
Corrective Feedback and Multimodality: Rethinking Categories in Telecollaborative Learning
}

\section{Ana Freschi \& Suzi Cavalari}

Teletandem (Telles, 2009) is a model of telecollaboration in which pairs of foreign language students from different countries meet regularly and virtually to learn each other's languages. Within this context, participants are expected to help their partners learn by providing feedback. The multimodal nature of this type of environment, however, may offer different learning opportunities (Guichon \& Cohen, 2016) and have an impact on feedback provision. This research aims at investigating peer corrective feedback in Teletandem in relation to the different modes. Using a case study approach, we describe how three Brazilians offered feedback to learners of Portuguese as a foreign language. Data used came from 20 Teletandem oral sessions that took place over a period of three years and were stored in MulTeC (Aranha \& Lopes, 2019). Data analysis revealed that CF provision is characterized by reformulations, with a blurred distinction between recasts and explicit corrections due to a combination of multimodal strategies. Results also indicate that error correction may be more (or less) emphasized depending on how interlocutors combine multimodal resources. Pedagogical implications are discussed.

Teletandem (Telles, 2009) est un modèle de télécollaboration par lequel des paires d'étudiants de langue étrangère originaires de différents pays se rencontrent régulièrement de façon virtuelle pour apprendre les langues des uns des autres. Dans ce contexte, on s'attend à ce que les participants aident leur partenaire à apprendre en leur fournissant de la rétroaction. La nature multimodale de ce type d'environnement peut, cependant, offrir diverses occasions d'apprentissage (Guichon \& Cohen, 2016) et influencer la façon dont la rétroaction est fournie. Le but de cette recherche est d'étudier la rétroaction corrective par les pairs dans Teletandem par rapport aux différents modes. En se servant d'une approche par étude de cas, nous décrivons comment trois Brésiliens ont offert de la rétroaction à des apprenants de portugais langue étrangère. Les données utilisées venaient de 20 sessions orales de Teletandem qui s'étaient déroulées sur une période de trois ans et ont été stockées sur MulTeC (Aranha \& Lopes, 2019). L'analyse des données a révélé que la fourniture de rétroaction corrective se caractérise par des reformulations, qui ne distinguent pas très bien entre des refontes et des corrections explicites, ce qui est dî̀ à une combinaison de stratégies multimodales. Les résultats indiquent également que la correction des erreurs peut être plus ou moins soulignée selon la façon dont les interlocuteurs combinent les ressources multimodales. On discute des implications pédagogiques.

Keywords: telecollaboration, Teletandem, corrective feedback, multimodality 
Teletandem (Telles, 2009) is a bilingual model of telecollaboration which uses videoconferencing technology (such as Skype) to promote interaction between pairs of learners who are proficient (or native) speakers of different languages and live in different countries so that they can learn each other's language. As a videoconference-based exchange in foreign language, Teletandem (TTD) environment integrates aural, visual, and written (chat) modes of communication.

According to Guichon and Cohen (2016), the multimodal nature of this type of environment may offer different learning opportunities. The authors remark that, in synchronous interactive learning contexts, the integration of aural and visual modes may enhance students' comprehension and the combination of voice and text chat may favour negotiation of meaning. They also argue that "different modes available in synchronous interactive environments are interrelated and the learning opportunities offered will depend on how users choose to combine or dissociate the different modes" (p. 7). In this respect, some studies (Guichon \& Wigham, 2016; Hampel \& Stickler, 2012; Wigham \& Chanier, 2015; Wigham, 2017) have revealed that modes can be combined by users in a complementary, compensatory, or competitive fashion.

The present study is based on the premise that the use of different semiotic resources may have an impact on corrective feedback $(\mathrm{CF})$ provision during Teletandem oral sessions. It is also based on the notion that CF plays a crucial role in language learning. There is a vast literature on the types and effectiveness of corrective feedback in the foreign language classroom (Allwright \& Bailey, 1991; Battistella, 2015; Cavalari, 2008; Ellis, 1985; Lyster \& Saito, 2010; Lyster et al., 2013; Mackey \& Goo, 2007; Nassaji, 2015, 2016; Nassaji \& Kartchava, 2017; Ranta \& Lyster, 2007; Ur, 1996). More recently, we have witnessed a growing body of studies on CF in telecollaborative settings (Akiyama, 2017; Freschi, 2017; Cavalari \& Freschi, 2018; Furtoso, 2011; Ware \& Cañado, 2007; Ware \& O'Dowd; 2008). However, there have been few investigations to date (Wigham \& Chanier, 2015; Ziegler \& Phung, 2019) which discussed feedback in synchronous computer-mediated communication (SCMC), specifically telecollaborative language learning, from within a multimodal perspective. A description of how different modes are combined in CF provision in virtual exchanges may evidence specificities of feedback in this type of learning setting and inform pedagogical assistance to learners.

In this study, we aim to examine peer corrective feedback (peer responses to fellow learner's utterances containing an error) in TTD in relation to the different modes used to communicate. We intend to do so by analyzing the same data used by Freschi (2017) but from a multimodal perspective. That study investigated peer feedback in Teletandem oral sessions and showed that recasts and explicit correction (Ranta \& Lyster, 2007) are the most common CF provided by TTD peers. Results also revealed subcategories 
within these two CF types which could be described in relation to the multimodal nature of the environment. However, the analysis did not take multimodality into consideration. The question we set out to answer in the present investigation is: How does a combination of aural, textual, and visual modes of communication impact corrective feedback provision in Teletandem oral sessions?

\section{Telecollaboration and Teletandem}

"Telecollaboration" is an umbrella term that has been widely used in the area of foreign language education to refer to institutionalized, technologymediated intercultural communication under the guidance of a teacher for the purposes of foreign language (and cultural) learning (Belz, 2003; Guth \& Helm, 2010; Warschauer, 1996). More recently, "Virtual Exchange" ${ }^{11}$ has emerged (Helm, 2018; O'Dowd, 2019) as an alternative term to refer to

the engagement of groups of learners in extended periods of online intercultural interaction and collaboration with partners from other cultural contexts or geographical locations as an integrated part of their educational programmes and under the guidance of educators and/or expert facilitators. (O’Dowd, 2018, p. 5)

These definitions seem to indicate that both telecollaboration and virtual exchange are terms that refer to the same concept and, for this reason, they are used interchangeably in this paper. We acknowledge, nonetheless, that these concepts can be materialized in varied contexts, by means of different approaches, with a diverse combination of technological resources. Lewis and O'Dowd (2016) and O'Dowd (2018) provide an overview of telecollaborative initiatives, highlighting the approaches, the associated terminology, the main characteristics, and the technology often used. These studies reveal that despite the growing interest among teachers of different disciplines in implementing virtual exchanges, most telecollaborative initiatives are aimed at promoting foreign language (and cultural) learning.

Table 1 shows a summary of the most relevant features presented by O'Dowd (2018) in the area of telecollaborative foreign language learning. 
Table 1

Virtual Exchange and Language Learning (based on O'Dowd, 2018)

\begin{tabular}{llll}
\hline Discipline & Associated terminology & Main characteristics & Technologies \\
\hline Foreign & - telecollaboration & - often bilingual & - email \\
language & - online intercultural & - foreign language & - forum \\
learning & exchange & competence & - website \\
initiatives & - e-tandem & - intercultural & - video \\
& - Teletandem & communicative & - blog \\
& - Computer Assisted & competence & - chat room \\
& Language Learning (CALL) & - digital competence & - audio call \\
& - Network Based Language & & - videoconferencing \\
& Teaching (NBLT) & &
\end{tabular}

Among the possibilities presented in Table 1, we focus on the TTD initiative, which involves bilingual synchronous exchanges (carried out by means of videoconferencing technology). In Telles's (2015) words, Teletandem is

a virtual, collaborative and autonomous context for learning foreign languages in which two students help each other to learn their own languages (or language of proficiency). They do so by using the text, voice and webcam image resources of VOIP technology (such as Skype), and by adopting the three principles of tandem learning: autonomy, reciprocity, and separate use of languages (Brammerts, 2003; Telles \& Vassallo, 2006). (p. 604)

This definition emphasizes the roles of technology and of the theoretical principles which guide language learning in TTD: each participant is expected to (i) be responsible for their own learning in collaboration with their partner (autonomy), (ii) collaborate/commit to their partner's learning (reciprocity), and (iii) practise one language at a time, dedicating the same amount of time to both languages involved (separation of languages). However, the roles played by the institutions and the teachers are not explicitly defined as there is no mention to the relevance of institutional support and pedagogical assistance, which are key elements in the characterization of the learning set up (Cavalari, 2018; Cavalari \& Aranha, 2016).

In the present study, we focus on an institutionally integrated model of Teletandem in which the virtual exchange is recognized by the higher education institutions in both countries and is embedded into the foreign language classroom on both sides of the partnership. According to Cavalari and Aranha (2016), integrating TTD into the syllabus and pedagogical practice entails (i) preparing participants, (ii) designing tasks which make meaningful connections between virtual exchange and classroom (face-to-face) learning, and (iii) integrating assessment performed by the different agents involved 
in the learning process: the teacher, the learner, and their foreign language partner. From a formative perspective ${ }^{2}$ (focus on the learning process), feedback can be considered the learning element of assessment. In this sense, understanding the specificities of feedback in TTD settings may contribute to the advancement of theoretical discussions and promotion of meaningful integration of virtual exchanges into the foreign language curriculum. In this paper, we focus on the specificities of corrective feedback in TTD oral sessions, i.e., the feedback provided by the native (or more proficient) speaker to the foreign language learner during videoconference-based interactions.

\section{Multimodality}

Multimodality is defined by Kress and Van Leeuwen (2001, p. 20) as the "use of several semiotic modes in the design of a semiotic product or event, together with the particular way in which these modes are combined." Guichon and Cohen (2016, p. 2) define mode as the "type of semiotic representation (textual, aural, visual) used to present information" and modality as "the semiotic realization of one mode" (i.e., the realization of visual mode in videoconference-based interactions). The authors consider multimodality a defining characteristic of CALL and propose a framework to describe and discuss how different modes and media may be combined in multimodal environments. According to the authors, media are "the technological means of inscription and production that shape the ways any message is conveyed and accessed" (p. 2). Media are characterized as static (an online dictionary), dynamic (a video clip), or interactive (a videoconferencing conversation). In terms of temporality, communication supported by different media may be asynchronous (production and reception are not simultaneous in time) or synchronous (production and reception are simultaneous in time).

Within CALL, there is an increasing number of studies which have focused on how multimodality may foster language teaching and learning (Early et al., 2015; Guichon \& Cohen, 2016; Hampel \& Hauck, 2006; Jewit, 2012; Wigham \& Chanier, 2015). There are, nevertheless, few studies (Guichon \& Wigham, 2016; Hampel \& Stickler, 2012; Wigham, 2017; Ziegler \& Phung, 2019) carried out within contexts that combine textual, visual, and oral modes, and interactive synchronous media (i.e., videoconference and text chat), like the TTD environment.

Hampel and Stickler (2012) investigated the use of videoconferencing in an online language program to find out how teacher-students interaction was influenced by the affordances of the environment. Results revealed that some discourse functions appeared across both modes: (i) social conversations (greetings and farewells), (ii) management of technology, (iii) negotiating meaning (related to the task), (iv) off-task conversations amongst students, and (v) teacher feedback. In relation to feedback provision, the authors 
remark that the teachers used the text chat to (i) respond to a student's spoken contribution, (ii) respond to a student's query, (iii) recast or model language in writing, and (iv) summarize the spoken discussion.

The research also evidenced an interplay of the oral and the written modes. In fact, there were three ways in which the modes were combined during interaction: to complement each other, to compensate for shortcomings, or in competition with each other. Complementation was most common when input in one mode triggered a response in another. Teachers used this approach to give written feedback to students' contributions, for example. According to the authors, there seems to be two reasons for using text chat as complementary to audio: text provides a more permanent record of an interaction and both students and teachers could contribute to the discussion without having to interrupt the speaker. Compensation was observed when users perceive (i) lack in one mode (e.g., a participant resorted to chat because of audio problems), or (ii) personal difficulties in using one modality (e.g., difficulties with typing, or anxiety about speaking). Competition was characterized by conversations taking place simultaneously in the aural mode and the text chat. The authors remarked that some of these parallel conversations concerned discussions on the topic in one modality and advice or comments about the technology in the other channel.

Guichon and Wigham (2016) investigated the meaning-making potential of the webcam in pedagogical interactions from a semiotic perspective within a telecollaborative project. The study showed that even though a head and shoulders framing shot was favoured by the participants, this framing choice did not seem optimal for desktop videoconferencing because there was a loss between the number of gestures performed by the interlocutor and what the learner could actually see. It was also evidenced that mutual comprehension was enhanced when participants were able to coordinate audio with communicative gestures and hold gestures long enough to be perceived by the learners.

Wigham's (2017) study focused on lexical explanations in virtual exchanges via video conferences and text chat. The analysis revealed that while the visual mode was used to project active listening, the audio was used to highlight the lexical item whereas the text chat (in a complementary role) was used to help establish common ground in relation to the item.

Ziegler and Phung (2019) investigated the extent to which modes of SCMC impact the quantity and quality of interactional features in second language task-based interaction. Participants were 20 English learners from a public university in Vietnam who had to perform a story-based jigsaw task and interact with two Americans interlocutors. They had to use different modes in their interactions: audio-chat, video-chat, text-chat, and multimodal chat. Findings indicate that the multimodal interaction had the largest portion of $\mathrm{CF}$ and, according to the authors, multimodality can provide language learning opportunities. 
Considering that TTD is a videoconference-based exchange, we assume that meaning is constructed synchronously and collaboratively via linguistic interaction using aural (participants' voices through the microphone), visual (images conveyed by the camera), and textual (written chat) modes. Among the many aspects that may contribute to language learning, we focus on corrective feedback, aiming to characterize the interplay of modes.

\section{Corrective Feedback}

Corrective feedback (CF) can be defined as "responses to learner utterances containing an error" (Ellis, 2006, p. 28). This definition, however, does not explicitly mention the agent who provides the responses to learner "erroneous" utterances; in fact the large body of literature on CF reveals that it may be provided by teachers and peers, or be requested by learners (Buckwalter, 2001; Debras et al., 2015; Lyster \& Ranta, 1997; Mackey et al., 2003, Nassaji \& Karchava, 2017; Sato, 2017; Shehadeh, 2001). In this study, we are interested in the specificities of peer corrective feedback in bilingual telecollaborative settings.

In regard to oral CF types, research on peer feedback has drawn on the seminal study by Lyster and Ranta (1997), who proposed six categories of CF based on a descriptive approach to teacher's practice in L2 classrooms. The CF types found were: (i) explicit correction (clear linguistic indication of an error followed by the correct form); (ii) recast (reformulation of the utterance with correct form); (iii) clarification requests (indication of an error by asking questions), (iv) metalinguistic feedback (comments about an error without the correct form), (v) elicitation (demanding of the correct form); and (vi) repetition (repetition of the error).

These categories were later reorganized by Ranta and Lyster (2007) into two groups: (1) reformulation, which "includes recasts and explicit correction because both these moves supply learners with target reformulations of their non-target output" (p.152), and (2) prompts, which "include a variety of signals, other than alternative reformulations, that push learners to selfrepair" (p. 152). In the latter group, clarification requests, metalinguistic feedback, elicitation, and repetition are included. According to the authors, $\mathrm{CF}$ in the first group is explicit because it provides the correct form, and in the second group is implicit because it withholds correct forms and instead clues to prompt students to retrieve these correct forms from their existing knowledge.

In their state-of-the-art article, Lyster et al. (2013) presented these CF categories in relation to the discussion made by Sheen \& Ellis (2011) on the distinction between reformulations and prompts, and between implicit and explicit CF. Table 2 is based on the authors' proposal: 
Table 2

CF types (Lyster et al., 2013 adapted from Ranta \& Lyster, 2007; Sheen \& Ellis, 2011)

\begin{tabular}{|c|c|c|}
\hline & Implicit & Explicit \\
\hline \multirow[t]{5}{*}{ Reformulations } & Conversational recasts & Didactic recasts \\
\hline & $\begin{array}{l}\text { - a reformulation of a student } \\
\text { utterance in an attempt to } \\
\text { resolve a communication }\end{array}$ & $\begin{array}{l}\text { - a reformulation of a student } \\
\text { utterance in the absence of a } \\
\text { communication problem }\end{array}$ \\
\hline & breakdown & Explicit correction \\
\hline & $\begin{array}{l}\text { - often take the form of } \\
\text { confirmation checks }\end{array}$ & $\begin{array}{l}\text { - a reformulation of a student } \\
\text { utterance plus a clear indication of } \\
\text { an error }\end{array}$ \\
\hline & & $\begin{array}{l}\text { Explicit correction with metalinguistic } \\
\text { explanation }\end{array}$ \\
\hline \multirow[t]{8}{*}{ Prompts } & Repetition & - in addition to signalling an error and \\
\hline & $\begin{array}{l}\text { - a verbatim repetition of a } \\
\text { student utterance, often with }\end{array}$ & $\begin{array}{l}\text { providing the correct form, there is } \\
\text { also a metalinguistic comment }\end{array}$ \\
\hline & $\begin{array}{l}\text { adjusted intonation to highlight } \\
\text { the error }\end{array}$ & Metalinguistic clue \\
\hline & $\begin{array}{l}\text { Clarification request } \\
\text { • a phrase such as 'Pardon?' }\end{array}$ & $\begin{array}{l}\text { - a brief metalinguistic statement } \\
\text { aimed at eliciting a self-correction } \\
\text { from the student }\end{array}$ \\
\hline & $\begin{array}{l}\text { and I don't understand' } \\
\text { following a student utterance to }\end{array}$ & Elicitation \\
\hline & indirectly signal an error & $\begin{array}{l}\text { - directly elicits a self-correction from } \\
\text { the student, often in the form of a } \\
\text { wh-question }\end{array}$ \\
\hline & & Paralinguistic signal \\
\hline & & $\begin{array}{l}\text { - an attempt to nonverbally elicit the } \\
\text { correct form from the learner }\end{array}$ \\
\hline
\end{tabular}

According to the authors, there is a continuum that ranges from implicit to explicit both in the reformulation and in the prompt groups:

- prompts range from clarification request (the most implicit) to metalinguistic clue (the most explicit); repetition, paralinguistic signal and elicitation are intermediary forms;

- reformulations range from conversational recasts (the most implicit) to explicit correction with metalinguistic explanation (the most explicit); didactic recast and explicit correction are intermediary forms.

It is clear that description of CF types has evolved over the years as more details have been incorporated in the definition of the categories; for example, "explicit correction with metalinguistic explanation" or "conversational recast" as opposed to "didactic recasts." 
Regarding the interlocutors involved in oral interactions in (Tele)tandem, dyads are characterized as native and non-native speakers (or L1 speakers and L2 learners). Research from within an interactionist perspective (Gass, 1997; Mackey et al., 2003; Sato, 2015, 2017; Shehadeh, 2001) has revealed that learners receive more CF in L1-L2 speaker interactions than in peer interactions (L2-L2 speakers). However, modified output to nontarget utterances seems to be more frequent when $\mathrm{CF}$ is provided by a fellow learner.

It is relevant to note, however, that there is a pivotal feature of TTD setting which distinguishes it from other L1-L2 speaker interactions. TTD practice is guided by the principles of autonomy, reciprocity, and separation of languages. This means that participants take turns in the role of the more proficient (L1) speaker and the L2 learner and negotiate their learning needs and preferences so that both of them can benefit from the interaction. In this respect, Cappellini et al. (2020) examined TTD participants' views on reciprocity. The data collection instrument used was learning logs written by participants in three different partnerships: Brazil-Germany, USAFrance, and Australia-France. Results showed that learners tend to relate the reciprocity principle to "the social relationship, either concerning the affective and emotional dimensions contributing to a friendly climate, or searching for mutual interests in co-constructing an online third space" (Dooly, 2011, Conclusion section, para. 3). This seems to indicate that TTD participants perceive each other as L2 learners who should collaborate with each other.

According to Storch (2002), who investigated patterns of interaction between pairs of L2 learners, this "collaborative and expert/novice pattern" is more conducive to L2 learning. From within a sociocultural framework, L2 learning emerges in interaction when learners establish a collaborative relationship. In Sato's (2017) words,

L2 learning can be conceptualized based on the way in which learners assist each other's learning and achieve a level that they would not necessarily be able to achieve on their own. This support and the subsequent language exchanges is called scaffolding. In this framework, PCF [Peer Corrective Feedback] can serve as a mediational tool for scaffolding through which learners 'provide expertise to each other' (Brooks \& Swain, 2009, p. 69). (p. 23)

Considering peer interaction in bilingual telecolaborative language settings, Zourou (2009) discussed CF in relation to the concepts of symmetry and interaction. The author made a review of the studies on error correction practices and juxtaposed peer feedback in tandem to tutor feedback in virtual exchanges between pre-service teachers and L2 learners. She concludes that, on the one hand

in asymmetrical tutor-learner interaction, where partners' roles and tasks are clearly defined, pedagogical skills in error noticing 
and correction are crucial. Further investigation into the types, modalities, strategies and amount of corrective feedback in relation to the maintenance of smooth interaction is needed in order to develop a better understanding of the interactional processes of feedback delivery in CMC settings. (Zourou, 2009, p. 16)

On the other hand, the symmetry in tandem interactions seems to offer a less face-threatening environment as "learners are engaged in sustainable online interaction and they do not feel they should provide feedback" ( $\mathrm{p}$. 16). The author remarks that the peer's role is to facilitate exchange in a less threatening environment, and error correction may be a task that language learners in tandem cannot fully carry out.

Although we agree with the author on the role played by peers, we argue that error correction in (Tele)tandem settings may be a task that learners carry out in particular ways exactly because they seem to recognize their symmetrical status and collaborative relationship. One particular trait found in investigations on (Tele)tandem context is the fact that peer CF provision is characterized mostly by recasts (and explicit correction to a lesser extent) even when participants receive training on the different types of CF (Akiyama, 2017; Freschi, 2017; Cavalari \& Freschi, 2018; Ware \& O'Dowd, 2008).

Akiyama (2017) investigated peer CF in relation to learners' beliefs within synchronous video-based eTandem ${ }^{3}$ exchange between 12 Japanese (learners of English) and 12 Americans (learners of Japanese). The research used survey data from 24 participants, interactional data in Japanese from six dyads and interview data from five learners (both Japanese and Americans). After training the participants on corrective feedback, based on Lyster and Ranta's (1997) categories, recasts proved the most frequent way of providing feedback, followed by explicit correction and clarification requests. The qualitative analysis revealed that participants preferred recasts because they are perceived as immediate, timesaving, unintrusive, and easy to provide. Results also showed that some learners considered recasts implicit while others perceived them as explicit. According to the author, this difference in learner perception is "most likely related to interactional contexts (Lyster \& Mori, 2006; Nabei \& Swain, 2002; Ware, 2004) and individual differences such as working memory (Li, 2013; Mackey \& Sachs, 2011), analytical ability (Li, 2013), the level of anxiety (Sheen, 2008), and beliefs (Kartchava \& Ammar, 2014)" (p. 68).

Akiyama argues that the preference for recasts and the scarcity of $\mathrm{CF}$ types that are pedagogically oriented (like prompts) can be attributed to the fact that participants viewed themselves as a friend rather than a tutor and, therefore, wanted to save face by avoiding explicit error correction. She points out that this seems to resonate with the notion that recasts are conversationally orientated (Lyster \& Saito, 2010) and pedagogically 
"expeditious, less threatening to student confidence, and less intrusive to the flow of interaction" (Loewen \& Philp, 2006, p. 551).

In Teletandem, feedback to oral production has been studied by Benedetti and Gianini (2010), Furtoso (2011), Freschi (2017), and Cavalari and Freschi (2018). Benedetti and Gianini (2010) studied how a Brazilian learner of Spanish provided feedback to an Argentinian in a Portuguese-Spanish partnership. Due to one of the participant's technical problems, $70 \%$ of data were recorded in chat and 30\% in audio and video. They found that explicit correction and recasts were the most used $\mathrm{CF}$ in both data types. According to the author, this result reveals the more competent learner's attempt to provide the less competent with the correct form while maintaining the flow of communication.

Furtoso (2011) investigated the features of spoken Portuguese and oral proficiency assessment in Teletandem. Data used were recordings of oral interactions between four pairs of participants: learners of Brazilian Portuguese and German, and French and English. Although CF was not the main focus of the study, the analysis revealed that partners used aural, written and visual modes to provide feedback. According to the author, feedback was seen as an opportunity for meaningful and contextualized learning because it allowed TTD partners to receive immediate, timely, and evaluative information in relation to their foreign language learning.

Freschi (2017) studied peer CF in Teletandem oral sessions in Portuguese. The data set she used was the same we use in this study: recordings of oral sessions generated by three pairs of participants: Brazilians (learners of English) and Americans (learners of Portuguese) (please refer to the methodology section for further details). The analysis revealed that the only CF types used by the participants were recasts (reformulation of a sentence without the error) and explicit correction (clear indication of an error followed by correct form explicit provision). This result corroborates findings in Akiyama's and Benedetti and Gianini's studies. Results also showed subcategories of each CF type which could be organized within a continuum of explicitness. Figure 1 shows the specificities of feedback categories based on how explicit they are. 


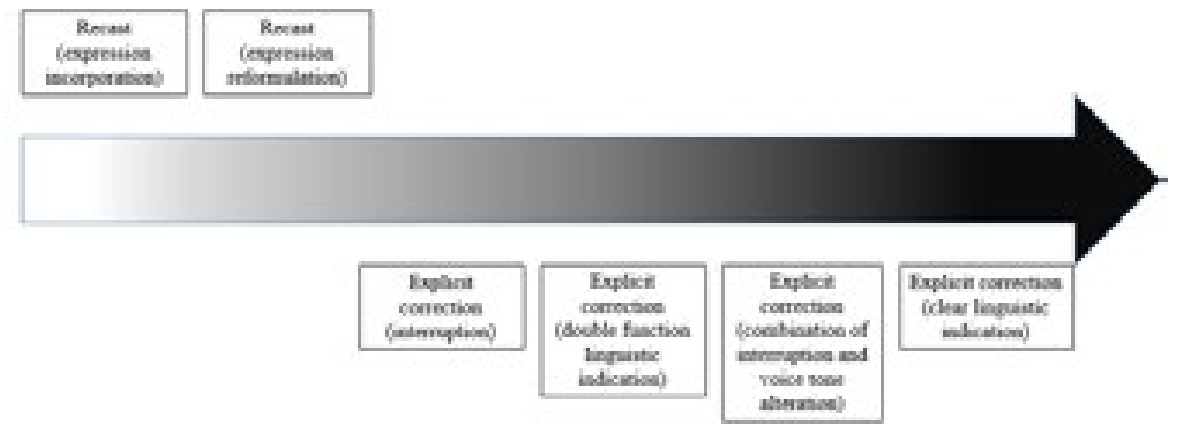

The continuum suggests that the subcategories within recast and explicit correction are based on the researcher's interpretation of verbal and nonverbal clues. According to Freschi, recasts can be provided in two ways:

(i) a less explicit subcategory, when partners incorporate the correct linguistic form in their sentences;

(ii) a more explicit subcategory, when they reformulate just part of the sentence where there is an error.

Due to the contextual characteristics (which include autonomy and reciprocity), the author only considered feedback as recast when it was possible to actually see that there was no interruption to the learner's discourse. The author also described four subcategories of explicit correction:

(i) interruption of the less competent partners' sentence to offer the correct form;

(ii) double function linguistic indication, which is the indication of the correct form followed by a reformulation of the correct sentence (for example, learner says "he are a teacher," and partner says "is, he is a teacher");

(iii) combination of interruption and voice tone alteration to reformulate the correct form; and

(iv) clear linguistic indication, which is an expression to show a misunderstanding followed by the correct form.

The author states that some strategies (tone of voice, facial expressions) were used to signal the error and provide the correct form in an attempt to save face for the partner during oral interaction. However, the analysis was not grounded on multimodality theoretical framework, which justifies the fact that the present study uses the same data sample.

A few studies considered multimodality for feedback provision in online contexts and telecollaboration. For example, Guichon et al. (2012) examined the provision of feedback by teacher-trainees from a multimodal perspective. 
Results revealed various strategies across different modalities which were based on the teachers' personal preferences. The findings include verbal recasts as the most used strategy, followed by writing the correct form in the text chat, which was used not to interrupt the communicative flow. The authors also discussed that webcam image was barely exploited for $\mathrm{CF}$ provision. These findings highlight the relevance of training teachers in the skills needed to perform in multimodal teaching contexts so that they do not become cognitively overloaded and subsequently reduce feedback provision.

Wigham and Chanier (2015) used multimodal transcriptions to study how feedback is provided in the synthetic world of Second Life. Their analysis revealed that (i) feedback concerned (mostly) lexical errors and was provided in the form of recasts, (ii) text chat was used for content-based interaction related to the task as well as for feedback concerning nontarget-like errors in the audio modality, and (iii) the multimodality of the environment did not appear to cognitively overload students who frequently responded in the audio modality to corrective feedback offered in the text chat.

In a face-to-face tandem context, Debras et al. (2015) studied how four undergraduate students (two speakers of French and two speakers of English) provided CF while participating in a speaking game called Liar, Liar (in which the native listener has to identify three lies in their partner's personal story). They investigated corrective feedback in relation to focus (what is corrected), type (categories found in Lyster \& Ranta, 1997), request (if feedback was requested by the learner or not), and uptake (the learner's utterance right after the feedback provision). Also, they analyzed feedback provision, request, and uptake in relation to verbal content, vocal features, and gestures. The study revealed that (i) recast was the most frequent type of feedback, (ii) vocabulary errors were the most frequently corrected, (iii) feedback was requested $57 \%$ of the time, not requested $40 \%$ of the time, and $3 \%$ of the time it followed a hesitation on the part of the learner, and (iv) feedback is followed by learner's uptake most of the times (66\% uptake and $12 \%$ partial uptake). For the authors, the most relevant results concerned the multimodal nature of feedback: nearly $90 \%$ of all feedback occurrences (considering provision, request, and uptake) were multimodal in that they "include[d] verbal, vocal and visual resources" (p. 19).

These studies have shown that (i) the relationship established by participants in virtual exchanges seems to have an impact on the interaction and on $\mathrm{CF}$ provision, and (ii) recast is the most frequent CF type in telecollaborative learning settings. Although many of the studies reviewed did not aim to discuss multimodality, taken together, their results suggest that modality seems to have an impact in feedback provision and meaning negotiation. Hence, this study has set out to determine how the combination of aural, textual, and visual modes of communication impacts corrective feedback provision in Teletandem oral sessions. 


\section{Method}

The present study utilized a descriptive, case study approach with the purpose of examining the data within a specific context. According to Zainal (2007), a case study is characterized by focusing on a small geographical area or on a very limited number of individuals as the subjects of study. As such, the case study reported in this paper examined corrective feedback provision by three Brazilian participants in institutionally integrated Teletandem.

\section{The Context and the Data}

Teletandem is implemented across three campuses at a large university in Brazil. The data examined in this paper were generated at one of the campuses, within an institutionally integrated model. This model, according to Cavalarir and Aranha (2016), is characterized by incorporation of the following tasks into the foreign language programs: (i) answering questionnaires (an initial (pre-project) questionnaire and a final one); (ii) attending a tutorial (orientation meeting), aimed to offer students an overview of the project; (iii) participating in Teletandem oral sessions (via Skype) with foreign language partners, (iv) writing learning diaries after each oral session ${ }^{4}$; (v) writing texts in the language students are learning (and receiving corrections on them); and (vi) correcting written productions from one's partner.

It is important to note that the tutorial informs the participants about the tasks they are to complete as well as the theoretical principles that guide TTD practice. This includes general information on feedback provision in relation to interaction during oral sessions. For example, participants are advised about the relevance of (i) negotiating how they would like to be corrected, (ii) considering the advantages and disadvantages of interrupting the conversation flow in order to correct or to be corrected, and (iii) considering alternatives to provide correction, such as using chat or email to pinpoint errors or aspects that could be improved.

Participants in institutionally integrated TTD talk to each other on Skype for approximately one hour on a weekly basis (for 8 weeks): half an hour in Portuguese and half an hour in English. The oral sessions are held in laboratories equipped with computers, webcams, and microphones, which means that all participants have access to image, voice and text chat during the conversations.

The data set used in this investigation was the same as that analyzed by Freschi (2017) and included 20 recorded Teletandem oral sessions between three Brazilians and their American partners. However, only the part in which the participants spoke Portuguese was analyzed, totalling $8 \mathrm{hr} 49 \mathrm{~min} 37 \mathrm{~s}$ of conversation. Selection of the data was based on the quality of the recorded sessions, i.e., considering optimal conditions to see and hear the participants. Table 3 shows the selected participants' information and data set used. 
Table 3

Focal Pairs Description and Data Set Used

\begin{tabular}{ll}
\hline Focal pairs description & Data set used \\
\hline $\begin{array}{l}\text { A012 is American, has been learning Portuguese for four years, and } \\
\text { speaks Spanish. }\end{array}$ & $\begin{array}{l}\text { Six recorded } \\
\text { sessions and chat } \\
\text { files. }\end{array}$ \\
B012 is Brazilian, is a senior, and works as an English teacher. & Eight recorded \\
A013 was born in Portugal, but has lived in the United States \\
since the age of three. She is a senior, said she has problems with \\
$\begin{array}{l}\text { Portuguese, and has already studied Spanish. } \\
\text { B013 is a Brazilian who is in the first year at university. }\end{array}$ \\
$\begin{array}{ll}\text { A014 is a 21-year-old American junior who has been studying } \\
\text { Portuguese for two years and a half and learned Spanish before } \\
\text { Portuguese. }\end{array}$ \\
$\begin{array}{l}\text { B014 is Brazilian who says she has problems with the English } \\
\text { grammar. }\end{array}$ \\
\hline
\end{tabular}

Source: adapted from Freschi (2017, p. 61).

These data are currently stored in MulTeC (Multimodal Teletandem Corpus) (Aranha \& Lopes, 2019; Lopes, 2019). Interactions were transcribed following the transcription guidelines set by Lopes (2019), which involved the insertion of transcriber's comments (between brackets) concerning technical problems, interruptions of the conversation, gestures (head nods and shakes, for example), laughs, intonation, hyperarticulation, and syllabication ${ }^{6}$.

It is important to note that, (i) Freschi (2017) did not take into account multimodal aspects in her analysis, and (ii) even though all participants had access to chat in all the oral sessions, only the chat files for the A012-B012 pair are stored in the corpus. According to Lopes (2019), who described data organization and systematization, missing files are attributed to technical problems (like corrupted files), or because participants did not save the files at all. As the authors were not present at data collection and were not responsible for the corpus organization, we assume that both problems may have contributed to the missing data in our sample.

\section{Data Analysis}

The first step in the analysis presented in this investigation was to verify which of the fragments that Freschi (2017) had coded as CF (any response to learner's erroneous oral production provided by the TTD partner) had been commented on by the transcriber in relation to the modes available to the participants in TTD oral sessions: textual (written chat), aural (the voice of the interlocutor through the microphone), and visual (the image conveyed by the 
webcam, text chat use or vocal features). This procedure revealed a significant number of fragments ( 72 out of 110 ) that could be analyzed through the lens of multimodality.

Then, based on the codes proposed by Debras et al. (2015), we proceeded to categorize $\mathrm{CF}$ occurrences according to the following features:

- verbal content: what is said;

- vocal features: how it is said (falling/rising tone, hyperarticulation, syllabication, tone imitation, laughs);

- gestures: hand gestures, head nods and head shakes, facial expressions (smile), mimicry;

- chat use (sometimes the transcriber mentioned the noise of keystrokes).

Some occurrences of chat use were mentioned by the transcriber; however, as the chat text file was not available in the MulTeC, we watched the video recordings that referred to those fragments in order to check if key strokes (typing) could be heard or if the participants looked down (to the keyboard). Finally, we used the (sub)categories established proposed in the Freschi's (2017) and Lyster et al.'s (2013) continua in order to further describe them in relation to multimodal features.

\section{Results}

Data analysis revealed that reformulation (recast and explicit correction) was the only type of feedback used by the Brazilian partners. Out of 72 occurrences of reformulations, 36 were categorized as recasts and 36 as explicit corrections. The different modes involved in CF were gestures (55 occurrences), vocal features $(n=22)$, and chat $(n=6)$, all of which seemed to play a complementary role in CF provision. We start our analysis by showing how gestures were used by the Brazilians.

\section{Fragment 1}

\begin{tabular}{ll}
\hline Original occurrence & Translated version \\
\hline A014: hum... quando eu estava em ensino médio? & A014: hum..when I was in high \\
$\left(\begin{array}{l}(B 014 \text { balança a cabeça afirmativamente) }) \ldots \text { hum:: } \\
\text { eu }\end{array}\right.$ & $\begin{array}{l}\text { school? ((B014 nods)))... hum.. I } \\
\text { B014: was it mandatory? }\end{array}$ \\
B014: era obrigatório? & A014: no no no it's not manda/to-ry \\
A014: não não não é obriga/ ga-tó-rio & B014: [mandatory ((smiles and \\
B014: [obrigatório ((sorri e balança a cabeça & nods)) \\
afirmativamente)) & $\begin{array}{l}\text { A014: I:: man-da-to-ry like that } \\
\text { hum:... I wan/wanted to do } \\
\text { A014: eu:: o-bri-ga-tó-rio assim hum:.... eu que/ } \\
\text { queria fazer todo... hum... mas... eu }\end{array}$ \\
\hline
\end{tabular}


In fragment 1, B014 and A014 are discussing sports practice in high school. The American has difficulty pronouncing the word "obrigatório" and the Brazilian interrupts her (in the transcription, interruptions are coded by [ ) and provides the correct form. This, according to Lyster et al. (2013), can be classified as a didactic recast. However, if we consider that interruption may evidence the error in the learner's utterance, this instance of CF could be an example of explicit correction with an interruption as per the Freschi's (2017) continuum. The fragment also shows that, besides the interruption, the gesture (head nod) and the facial expression (smile) used by B014 seem to make the correction explicit. These, however, seem to be used to soften the interruption and subsequent correction, which could have made the American learner uncomfortable. In this sense, the aural and visual (gestural) modes are combined in a complementary way to make error correction more explicit and, at the same time, face-saving for the partner.

The following fragment shows another use of multimodal CF involving gestures:

\section{Fragment 2}

\begin{tabular}{ll}
\hline Original occurrence & Translated version \\
\hline A013: hum sim obrigado muito & A013: hum yes very much thank you \\
$\begin{array}{l}\text { B013: muito obrigada ((balança a cabeça de } \\
\text { um lado para o outro)) }\end{array}$ & $\begin{array}{l}\text { B013: thank you very much ((moves } \\
\text { head from one way to another)) }\end{array}$ \\
$\begin{array}{l}\text { A013: eu escr/ hum muito obrigada hum eu... } \\
\text { eu... hum.. só vi por um pouquinho escrito com } \\
\text { muita pressa }\end{array}$ & $\begin{array}{l}\text { A013: I wro/ hum thank you very much } \\
\text { hum I... I... just saw for a short time in } \\
\text { a hurry }\end{array}$ \\
\hline
\end{tabular}

In this fragment, the American thanks the Brazilian for some comments she made regarding her written production. When A013 inverts the word order, saying "obrigado muito," B013 reformulates it, saying "muito obrigada," correcting the order of the words and also the gender ("obrigada") ${ }^{7}$. While this characterizes a recast with the expression reformulation (Freschi, 2017), the fact that the Brazilian moves her head sideways as she reformulates her partner's production seems to emphasize the right order of the words. In this sense, the gesture seems to be an indication of the error, which makes the correction explicit. Aural and visual (gestural) modes are combined to complement each other in CF provision and this seems to challenge the distinction between a recast and an explicit correction.

Fragments 3 and 4 reveal the role of vocal features in CF provision. 


\begin{tabular}{ll}
\hline Original occurrence & Translated version \\
\hline A012: são... os meus são/são verdes sim & A012: they are... mine are/are green yes \\
B012: muito comum aí no seu país né & $\begin{array}{l}\text { B012: very common there in your country } \\
\text { right }\end{array}$ \\
A012: até certo ponto eles/ os olhos & A012: to certain extent they/ colorado eyes \\
colorados pelo menos & at least \\
B012: coloRIdos ((entonação)) & B012: colored ((intonation)) \\
A012: coloridos... colorado é un um estado & $\begin{array}{l}\text { A012: colored... colorado is a a state } \\
((\text { risos)) }\end{array}$ \\
& $(($ laughs)) \\
\hline
\end{tabular}

The participants are talking about the American's eye colour, which the Brazilian thinks is a common trait for people born in the US. When the American agrees with her, he says "colorados." According to Freschi (2017), this is a recast with the expression reformulation, because B012 reformulates only the incorrect word. However, as the Brazilian does that, she stresses the correct syllable "coloRIdos." The vocal feature was used to emphasize the difference between "colorado" (Spanish word that means "colored red") and "colorido" (Portuguese word that means "coloured"). As B012 stresses the syllable to show where the problem was, the correction seems to become more explicit. In this case, it is a vocal feature (not a gesture), which seems to "blur" the distinction between a recast and an explicit correction. As we watch this moment of the interaction, we can't see any clear indication that the CF seems to be face-threatening for the American.

In Fragment 4, intonation and repetition are combined with facial expression to indicate an error in the reformulation.

\section{Fragment 4}

\begin{tabular}{ll}
\hline Original occurrence & Translated version \\
\hline $\begin{array}{l}\text { A013: hum yeah mi/ mi/ meus pais são mesmo } \\
\text { muito envolvido com o igreja mas eu não foi }\end{array}$ & $\begin{array}{l}\text { A013: hum yeah my/ my/ my parents are } \\
\text { really involved with the church but I was } \\
\text { em cinco seis anos assim }\end{array}$ \\
$\begin{array}{l}\text { not there in five six years like that } \\
\text { B013: been I haven't BEEN there in six } \\
\text { (levanta a sobrancelha e entonação no }\end{array}$ & $\begin{array}{l}\text { years ((raises eyebrows and stresses } \\
\text { been)) }\end{array}$ \\
A013: eu eu não vou há seis anos & A013: I haven't been there in six years \\
B013: hum hum... ah & B013: hum hum... ah \\
\hline
\end{tabular}

The partners were talking about going to the church when the American makes a mistake in the verb form: "eu não foi." B013 reformulates the expression, using "vou" and then repeats it with a rising intonation to 
indicate the error ("eu não VOU há seis anos"), which is an explicit correction with double function linguistic indication (Freschi, 2017). The Brazilian also raises her eyebrows as she says "vou" for the second time. These multimodal strategies maintain the conversational flow, signal the correct form but do not seem to be face-threatening. As we have no direct evidence on how the L2 learner interprets the feedback, we resorted to the images of the American's face, which does not reveal any discomfort or embarrassment.

A different way of using vocal features is shown in Fragment 5.

\section{Fragment 5}

\section{Original occurrence}

A014: face é::... ah:: tem mais lon/ longe

B014: longa ((com tom de pergunta))

A014: long yeah it's too long ((risos)) it looks longer without my bangs ah::

B014: não não acho é eu t/eu tenho o rosto um pouco longo só que eu engordei um pouco e agora parece um pouco menor porque tá mais redondo

\section{Translated version}

A014: face is:.... ah:: it has more dis/distant

B014: long ((question tone))

A014: long yeah it's too long ((laughs)) it looks longer without my bangs ah::

B014: no no I think hum I ha/have a long face but I put on some weight and now it looks a little smaller because it is rounder

In this fragment, the American was telling the Brazilian why she had her hair cut when she made an error saying her face was "longe" (distant), which does not make sense in Portuguese. B014 reformulates the expression saying the word "longa" (long) with a rising intonation (as in a question). Because the reformulation seems to aim at solving a communication breakdown, the CF could be categorized as a conversational recast (Lyster et al., 2013), or a recast with a confirmation check (Freschi, 2017). However, it should be noted that, from the Brazilian's point of view (who also speaks English as L2), there was no clear communication breakdown because the inference is obvious (when the American said "longe"(distant), she was obviously trying to say "longa" (long)). Therefore, if we consider the pedagogical implications of the reciprocity principle in TTD, B014's reformulation may be analyzed as a didactic recast and the rising intonation may be an attempt to save face for her partner.

Fragment 6 shows the last multimodal feature we discuss: the written chat. 


\begin{tabular}{ll}
\hline Original occurrence & Translated version \\
\hline A014: penso que muitos pessoas na & A014: I think that many people at university here I \\
universidade aqui eu sei muitos muitos & know many many christians because I'm christian \\
cristianos porque eu sou cristiano & So... I \\
então... eu & B014: AH! it's... \\
B014: AH! é... & A014: I'm chris...? \\
A014: eu sou cris...? & B014: christian ((types something)) \\
B014: cristã ((digita algo)) & A014: christian ((looks somewhere else at the \\
A014: cristã ((desvia o olhar da tela)) & screen)) \\
B014: sim & B014: yes \\
A014: ok cristã... então eu sou cristã & A014: ok christian... so I'm christian \\
\hline
\end{tabular}

In fragment 6, the American was trying to say that she is a Christian when she used the word "cristiano" (instead of "cristã"). The Brazilian explicitly tells her that there is a problem with the word, using the expression "AH! é..." and types the correct form in the chat, which is an explicit correction with a clear linguistic indication (Freschi, 2017). Although we do not have the actual text-chat data, keystrokes can be heard (as she types something on the keyboard), and, at the same time, the American looks at a different spot on her screen (probably the chat window). Following this change in gaze, she is able to say the word that she had been struggling with, suggesting that she had seen the correct form written in the chat. For this $\mathrm{CF}$, we can say that the chat was used to complement what was said by the Brazilian in providing the correct form. This finding seems to corroborate Guichon and Cohen's (2016) and Guichon et al.'s (2012) claim that the combination of aural, textual, and visual modes may enhance students' comprehension.

\section{Discussion and final considerations}

The results offer a nuanced answer to the question of how the combination of aural, textual, and visual modes of communication impact corrective feedback in Teletandem oral sessions. Data analysis showed that reformulation was the only category found and, within this category, recasts and explicit corrections were evenly used by Brazilian participants. This finding seems rather odd when compared to results of previous studies (Akiyama, 2017; Benedetti \& Gianini, 2010; Debras et al., 2015; Freschi, 2017; Zourou, 2009) that showed recasts as the most frequent feedback provided by peers in (Tele)tandem. Thus, the first aspect to be considered when answering our research question is whether the even number of recasts and explicit correction found in our data may be attributed to the fact that some fragments (e.g., fragment 2), 
which could be classified as recasts, are categorized in this study as explicit correction due to the inclusion of the multimodal perspective in the analysis.

In fact, our data suggest that considering a combination of different modes in CF provision made the distinction between recasts and explicit feedback unclear. This corroborates Lyster et al.'s (2013) and Freschi's (2017) proposals that CF categories should be viewed on a continuum. Feedback may become more or less explicit according to the varied forms in which vocal features, gestures (and/or facial expressions), and chat are combined during interaction. This is another aspect that seems to evidence how multimodality may impact feedback as detailed characterizations of CF (sub)categories along the continuum are enhanced by the varied (and sometimes subtle) nuances added by the combination of the modes available in TTD interaction.

There is no evidence in our data that the multimodal strategies used to signal the error may have been face-threatening for the partner. The images of the learner during CF provision do not reveal signs of discomfort or embarrassment. In this respect, it should be noted that other studies (Akiyama, 2017; Debras et al., 2015; Zourou, 2009) on peer CF in (Tele) tandem settings showed that participants seem to establish a collaborative relationship because they tend to see each other as "friends" rather than tutors. This symmetrical, collaborative relationship might prevent (or cushion) any discomfort caused by explicit error correction since participants perceive CF as the partner's attempt to help them learn. This result sheds light on one element of multimodal feedback that certainly deserves further empirical exploration since our data sample does not include direct evidence of learners' interpretation of CF.

It should be noted that these findings resonate with the literature on multimodality (Guichon \& Wigham, 2016; Hampel \& Stickler, 2012; Wigham, 2017) which has evidenced the interplay of the different modes in meaning making. In our data, the complementary fashion in which modes are combined is a key aspect of CF characterization: aural, gestural, and textual modes were used to maintain the conversation flow and, at the same time, make error correction more explicit without being face-threatening to the partner. In the cases when text-chat was combined with the other modes, it seemed to assist learners' comprehension of CF.

In summary, our findings reveal that

a. reformulation is the only CF category TTD partners used, but there seems to be a continuum of subcategories which range from implicit to explicit;

b. the different modes available in TTD oral sessions are combined in a complementary way during CF provision. Participants combined different semiotic resources to maintain the conversation flow while they make $\mathrm{CF}$ more or less explicit;

c. multimodal strategies used to make CF more explicit do not seem to be face- threatening for the learner; 
d. the combination of text-chat with the other modalities seem to enhance learner's comprehension of the feedback provided.

These results shed light on the affective and social aspects of CF provision and suggest context-specific traits of peer CF. Because multimodality seems to make error correction more evident without being face-threatening for learners, reformulation (in its varied forms) may be a CF category that is typical in interactions in which a symmetrical, collaborative relationship is established.

From a pedagogical perspective, our study's findings suggest that practitioners should explore the multimodal nature of TTD setting as a possibility to train participants in CF provision. This is in alignment with Ware and Cañado's (2007) proposal, which presents a rationale about how to incorporate grammar and feedback provision into telecollaboration. The authors propose that it is relevant to offer participants information about the difference between global and local mistakes and about indirect ways of providing and asking for feedback. Our results indicate that teachers could also inform participants on how they can use the different modes (e.g., gestures, text-chat, and tone of voice) to maintain the conversation flow while they provide $\mathrm{CF}$ to assist their partner's learning. It can be done, for example, by showing how multimodality is successfully used by different partners, especially in relation to the affordances of the text-chat.

Finally, further research that includes multimodal data in other languages and introspective data from instruments that could evidence the participant's perceptions is clearly needed in order to advance the discussion on the specificities (and to inform the practice) of peer CF in (Tele)tandem. Also, as the impact of multimodality in $\mathrm{CF}$ was also evidenced in a face-to-face tandem setting by Debras et al. (2015), the role of semiotic modes in CF provision within other language learning settings could contribute to the characterization of multimodal CF.

\section{Notes}

1. For a thorough discussion on terminology, refer to Lewis \& O’Dowd (2016) and O'Dowd (2018).

2. Assessment practice may be formative (when it is focused on the learning process) or summative (when it is focused on grading or classifying learning results).

3. eTandem is the term used in Europe (O'Rourke, 2007). Teletandem is the term used by Brazilian practitioners and researchers (Telles, 2009; Aranha \& Cavalari, 2014). 
4. Learning diaries are usually not written by American students. This depends on the teacher's decision.

5. A was used to refer to American students and B to the Brazilians. Numbers are related to the year they participated in Teletandem.

6. For further details on transcription guidelines, see Lopes (2019).

7. In Brazilian Portuguese, this expression is gender marked: "obrigada" (feminine) and "obrigado" (masculine).

\section{Acknowledgement}

The authors would like to thank the anonymous reviewers and the editors of this special issue for their insightful comments.

\section{The Authors}

Ana Carolina Freschi holds an MA in Applied Linguistics. She teaches EFL at Faculdade de Tecnologia (FATEC) Catanduva. She is also a PhD candidate in Applied Linguistics at Universidade Estadual Paulista (UNESP), where she researches assessment and telecollaborative learning.

Suzi Marques Spatti Cavalari holds an MA and a PhD in Applied Linguistics. She is associate professor of EFL at UNESP. Her research interests are telecollaborative language learning, assessment, and normalization of telecollaboration across the curriculum.

\section{References}

Akiyama, Y. (2017). Learner beliefs and corrective feedback in telecollaboration: A longitudinal investigation. System, 64, 58-73. https://doi.org/10.1016/j.system.2016.12.007

Allwright, D., \& Bailey, K. (1991). Focus on the language classroom. Cambridge University Press.

Aranha, S., \& Cavalari, S. M. S. (2014). A trajetória do projeto Teletandem Brasil: da modalidade institucional não-integrada à institucional integrada. The Especialist, 35(2), 183-201. https:// revistas.pucsp.br/esp/article/view/21467/15694

Aranha, S., \& Lopes, Q. B. (2019). Moving from an internal bank to a sharable multimodal corpus: the case of MulTeC. The ESPecialist, 40(1). https://doi.org/10.23925/2318-7115.2019v40i1a8

Battistella, T. R. (2015). Um olhar sociocultural sobre o feedback corretivo oral na sala de aula de língua estrangeira. [Doctoral dissertation, Universidade do Vale dos Sinos]. UNISINOS Campus Repository. http://www.repositorio.jesuita.org.br/bitstream/handle/ UNISINOS/3672/Tarsila+Rubin+Battistella.pdf;jsessionid=04974C825881973383BB62CD35F DA8D4?sequence $=1$

Belz, J. A. (2003). Linguistic perspectives on the development of intercultural competence in telecollaboration. Language learning \& technology, 7(2), 68-117. http://dx.doi.org/10125/25201

Benedetti, A. M., \& Gianini, F. (2010). O provimento de feedback no processo de ensino-aprendizagem de português/LE em telecolaboração. In A. M. Benedetti, D. A. Consolo, \& M. H. Vieira-Abrahão. (Eds.), Pesquisas em ensino e aprendizagem no Teletandem Brasil: línguas estrangeiras para todos (pp. 297-312). Pontes Editores.

Brammerts, H. (2003). Autonomous language learning in tandem: The development of a concept. In T. Lewis \& L. Walker (Eds.), Autonomous Language Learning in Tandem. Academy Electronic Publications Limited. 
Brooks, L., \& Swain, M. (2009). Languaging in collaborative writing: Creation of and response to expertise. In A. Mackey \& C. Polio (Eds.), Multiple perspectives on interaction: Second language research in honor of Susan M. Gass (pp. 58-89). Routledge.

Buckwalter, P. (2001). Repair sequences in Spanish L2 dyadic discourse: A descriptive study. The Modern Language Journal, 85(3), 380-397. https://doi.org/10.1111/0026-7902.00115 https://doi. org/10.1111/0026-7902.00115

Cappellini, M., Elstermann, A-K., \& Mompean, A. R. (2020). Reciprocity 2.0: How reciprocity is mediated through different formats of teletandem learners' logs. In C. Horgues \& C. Tardieu (Eds.), Redefining Language and Culture Tandem Learning in Higher Education. Routledge.

Cavalari, S. M. S. (2008). O gerenciamento do erro em aulas de inglês como língua estrangeira: um estudo com foco na produção oral. Trabalhos em Linguística Aplicada, 47(1), 45-63. https:// doi.org/10.1590/S0103-18132008000100004

Cavalari, S. M. S. (2018). Integrating telecollaborative language learning into Higher Education: A study on teletandem practice. Brazilian English Language Teaching Journal, 9(2), 417-432. https://doi.org/10.15448/2178-3640.2018.2.31927

Cavalari, S. M. S., \& Aranha, S. (2016). Teletandem: integrating e-learning into the foreign language classroom. Acta Scientiarum. Language and Culture, 38(4), 327-336. https://doi. org/10.4025/actascilangcult.v38i4.28139

Cavalari, S. M. S., \& Freschi, A. C. (2018). A correção de erros e as relações entre avaliação por pares e autoavaliação no ambiente teletandem. Revista do GEL, 15(3), 194-213. http://dx.doi. org/10.21165/gel.v15i3.2413

Debras, C., Horgues, C., \& Scheuer, S. (2015). The multimodality of corrective feedback in tandem interactions. Procedia-Social and Behavioral Sciences, 212(2), 16-22. https://doi.org/10.1016/j. sbspro.2015.11.292

Dooly, M. (2011). Crossing the intercultural borders into 3rd space culture(s). Language and Intercultural Communication, 11(4), 319-337. https://doi.org/10.1080/14708477.2011.599390

Early, M., Kendrick, M., \& Potts, D. (2015). Multimodality: Out from the margins of English language teaching. TESOL Quarterly, 49(3), 447-460. https://www.onlinelibrary.wiley.com/ doi/epdf/10.1002/tesq.246

Ellis, R. (1985). Understanding second language acquisition. Oxford University Press.

Ellis, R. (2006). Researching the effects of form-focussed instruction on L2 acquisition. AILA Review 19, 18-41. https://doi.org/10.1075/aila.19.04ell

Freschi, A. C. (2017). A avaliação por pares no teletandem institucional integrado: Um estudo de caso sobre o feedback linguístico nas sessões orais em português. [Master's thesis, Universidade Estadual Paulista]. UNESP Campus Repository. https://repositorio.unesp.br/bitstream/ handle/11449/149879/freschi_ac_me_sjrp.pdf?sequence=3

Furtoso, V. A. B. (2011). Desempenho oral em português para falantes de outras línguas: Da avaliação à aprendizagem de línguas estrangeiras em contexto online. [Doctoral dissertation, Universidade Estadual Paulista]. UNESP Campus Repository. https://repositorio.unesp.br/bitstream/ handle/11449/103505/furtoso_vab_dr_sjrp.pd?s

Gass, S. M. (1997). Input, interaction, and the second language learner. Lawrence Erlbaum.

Guichon, N., Bétrancourt, M., \& Prié, Y. (2012). Managing written and oral negative feedback in a synchronous online teaching situation. CALL, 25(2), 181-197. https://doi.org/10.1080/095 88221.2011.636054

Guichon, N., \& Cohen, C. (2016). Multimodality and CALL. In F. Farr \& L. Murray (Eds.), The Routledge handbook of language learning and technology (p. 509-521). Routledge.

Guichon, N., \& Wigham, C. R. (2016). A semiotic perspective on webconferencing supported language teaching. ReCALL, 28(1), 62- 82. https://doi.org/10.1017/S0958344015000178

Guth, S., \& Helm, F. (Eds.). (2010). Telecollaboration 2.0: Language, literacies and intercultural learning in the 21st century (Vol. 1). Peter Lang.

Hampel, R., \& Hauck, M. (2006). Computer-mediated language learning: Making meaning in multimodal virtual learning spaces. The JALT CALL Journal, 2(2), 3-18. http://oro.open.ac.uk/id/eprint/5418 
Hampel, R., \& Stickler, U. (2012). The use of videoconferencing to support multimodal interaction in an online language classroom. ReCALL, 24(2), 116-137. https://doi.org/10.1017/ S095834401200002X

Helm, F. (2018). Emerging identities in virtual exchange. Research-publishing.net.

Jewitt, C. (2012). Multimodal teaching and learning. The encyclopedia of applied linguistics.

Kartchava, E., \& Ammar, A. (2014). Learners' beliefs as mediators of what is noticed and learned in the language classroom. TESOL Quarterly, 48, 86-109. https://doi.org/10.1002/tesq.101

Kress, G., \& Van Leeuwen, T. (2001). Multimodal discourse. Arnold.

Lewis, T., \& O'Dowd, R. (2016). Introduction to online intercultural exchange and this volume. In T. Lewis \& R. O'Dowd (Eds), Online intercultural exchange: Policy, pedagogy, practice (pp. 3-20). Routledge.

Li, S. (2013). The interactions between the effects of implicit and explicit feedback and individual differences in language analytic ability and working memory. Modern Language Journal, 97(3), 634-654. https://doi.org/10.1111/j.1540-4781.2013.12030.x

Loewen, S., \& Philp, J. (2006). Recasts in the adult English L2 classroom: Characteristics, explicitness, and effectiveness. Modern Language Journal, 90, 536-556. https://doi.org/10.1111/ j.1540-4781.2006.00465.x

Lopes, Q. B. (2019). MulTeC: A construção de um corpus multimodal em teletandem. [Doctoral dissertation, Universidade Estadual Paulista]. UNESP Campus Repository. https:// repositorio.unesp.br/handle/11449/181353

Lyster, R., \& Mori, H. (2006). Interactional feedback and instructional counterbalance. Studies in Second Language Acquisition, 28(2), 269-300. https://doi.org/10.1017/S0272263106060128

Lyster, R., \& Ranta, L. (1997). Corrective feedback and learner uptake: Negotiation of form in communicative classrooms. Studies in Second Language Acquisition, 20, 37-66. https://doi. org/10.1017/S0272263197001034

Lyster, R., \& Saito, K. (2010). Oral feedback in classroom SLA: A meta-analysis. Studies in second language acquisition, 265-302. https://doi.org/10.1017/S0272263109990520

Lyster, R., Saito, K., \& Sato, M. (2013). Oral corrective feedback in second language classrooms. Language Teaching, 46(1), 1-40. https://doi.org/10.1017/S0261444812000365

Mackey, A., \& Goo, J. (2007). Interaction research in SLA: A meta-analysis and research synthesis. In A. Mackey (Ed.), Conversational interaction in SLA: A collection of empirical studies (pp. 408452). Oxford University Press.

Mackey, A., Oliver, R., \& Leeman, J. (2003). Interactional input and the incorporation of feedback: An exploration of NS-NNS and NNS-NNS adult and child dyads. Language Learning, 53(1), 35-66. https://doi.org/10.1111/1467-9922.00210

Mackey, A., \& Sachs, S. (2011). Older learners in SLA research: A first look at working memory, feedback, and L2 development. Language Learning, 62(3), 704-740. https://doi.org/10.1111/ j.1467-9922.2011.00649.x

Nabei, T., \& Swain, M. (2002). Learner awareness of recasts in classroom interaction: A case study of an adult EFL student's second language. Learning, Language Awareness, 11(1), 43-63. https://doi.org/10.1080/09658410208667045

Nassaji, H. (2015). How to draw learner's attention to form in communicative contexts: The use of interactional feedback. Contact Magazine, 41(4), 5-11. http://contact.teslontario.org/wpcontent/uploads/2016/04/ContactFall2015.pdf

Nassaji, H. (2016). Researching corrective feedback in interaction and instruction. Language Teaching Research, 20(4), 433-435. https://doi.org/10.1177/1362168816651018

Nassaji, H., \& Kartchava, E. (Eds.). (2017). Corrective feedback in second language teaching and learning: Research, theory, applications, implications. Routledge.

O'Dowd, R. (2018). From telecollaboration to virtual exchange: State-of-art and the role of UNICollaboration in moving forward. Journal of Virtual Exchange, 1, 1-23. https://doi. org/10.14705/rpnet.2018.jve.1

O'Dowd, R. (2019). A transnational model of virtual exchange for global citizenship education. 
Language Teaching, 1-14. https://doi.org/10.1017/S0261444819000077

O’Dowd, R., \& Lewis, T. (Orgs.). (2016). Online intercultural exchange: Policy, pedagogy, practice. Routledge Studies in Language and Intercultural Communication. Routledge.

O'Rourke, B. (2007). Models of Telecollaboration (1): eTandem. In R. O'Dowd (Ed.), Online Intercultural Exchange: An Introduction for Foreign Language Teachers (pp. 41-61). Multilingual Matters.

Ranta, L., \& Lyster, R. (2007). A cognitive approach to improving immersion students' oral language abilities: the awareness-practice-feedback sequence. In R. M. Dekeyser (Ed.), Practice in a second language: Perspectives from applied linguistics and cognitive psychology (pp. 141-160). Cambridge University Press. https://doi.org/10.1017/CBO9780511667275.009

Sato, M. (2015). Density and complexity of oral production in interaction: The interactionist approach and an alternative. International Review of Applied Linguistics in Language Teaching, 53(3), 307-329. https://doi.org/10.1515/iral-2015-0016

Sato, M. (2017). Oral peer corrective feedback. In H. Nassaji \& E. Kartchava (Eds.), Corrective feedback in second language teaching and learning: Research, theory, applications, implications (pp. 19-34). Routledge.

Sheen, Y. (2008). Recasts, language anxiety, modified output, and L2 learning. Language Learning, 58(4), 853-874. https://doi.org/10.1111/j.1467-9922.2008.00480.x

Sheen, Y., \& R. Ellis. (2011). Corrective feedback in language teaching. In E. Hinkel (Ed.), Handbook of research in second language teaching and learning, Vol. 2 (pp. 593-610). Routledge.

Shehadeh, A. (2001). Self- and other-initiated modified output during task-based interaction. TESOL Quarterly, 35(3), 433-457. https://doi.org/10.2307/3588030

Storch, N. (2002). Patterns of interaction in ESL pair work. Language Learning, 52(1), 119-158. https://doi.org/10.1111/1467-9922.00179

Telles, J. A. (2009). (Org.). Teletandem: um contexto virtual, autônomo e colaborativo para aprendizagem de línguas estrangeiras no século XXI. Pontes Editores.

Telles, J. A. (2015). Learning foreign languages in teletandem: Resources and strategies. DELTA: Documentação de Estudos em Lingüística Teórica e Aplicada, 31(3), 603-632. https://doi. org/10.1590/0102-4450226475643730772

Telles, J. A., \& Vassallo, M. L. (2006). Foreign language learning in-tandem: Teletandem as an alternative proposal in CALLT. The ESPecialist, 27(2). 189-212. http://citeseerx.ist.psu.edu/ viewdoc/download?doi=10.1.1.1025.2815\&rep=rep1\&type=pdf

Ur, P. A. (1996). A course in language teaching. Cambridge University Press.

Warschauer, M. (Ed). (1996). Telecollaboration in foreign language learning: Proceedings of the Hawaii Symposium, Vol. 12. Natl Foreign Lg Resource Ctr.

Ware, P. (2004). From involvement to engagement in online communication: Promoting intercultural competence in foreign language education. [Doctoral dissertation, University of California]. https://search.proquest.com/docview/305341761

Ware, P. D., \& Cañado, M. L. P. (2007). Grammar and feedback: turning to language form in telecollaboration. In R. O'Dowd (Ed.), Online intercultural exchange: An introduction for foreign language teachers (pp. 107-126). Multilingual Matters.

Ware, P., \& O'Dowd, R. (2008). Peer feedback on language form in telecollaboration. Language Learning \& Technology, (12)1, 43-63. http://dx.doi.org/10125/44130

Wigham, C. R., \& Chanier, T. (2015). Interactions between text chat and audio modalities for L2 communication and feedback in the synthetic world Second Life. Computer Assisted Language Learning, 28(3), 260-283. https://doi.org/10.1080/09588221.2013.851702

Wigham, C. R. (2017). A multimodal analysis of lexical explanation sequences in web conferencing supported language teaching. Language Learning in Higher Education, De Gruyter, Synchronous communication technologies in language and intercultural learning and teaching in higher education, 7(1), pp.81. https://hal.archives-ouvertes.fr/hal-01452031/ document

Zainal, Z. (2007). Case study as a research method. Jurnal Kemanusiaan, 5(1). https:// 
jurnalkemanusiaan.utm.my/index.php/kemanusiaan/article/view/165/158

Ziegler, N., \& Phung, H. (2019). Technology-mediated task-based interaction: The role of multimodality. International Journal of Applied Linguistics, 170(2), 251-276. https://doi. org/10.1075/itl.19014.zie

Zourou, K. (2009). Corrective feedback in telecollaborative L2 learning settings: Reflections on symmetry and interaction. The JALT CALL Journal, 5(1), 3-20. https://doi.org/10.29140/jaltcall. v5n1.70 